\title{
$\gamma$-irradiated prednisolone promotes apoptosis of liver cancer cells via activation of intrinsic apoptosis signaling pathway
}

\author{
FATUMA JUMAPILI RAMADHANI ${ }^{1,2}$, SEONG HEE KANG ${ }^{1}$, REMIGIUS AMBROSE KAWALA ${ }^{1,3}$, \\ BYUNG YEOUP CHUNG ${ }^{1}$, HYOUNG-WOO BAI ${ }^{1,2}$ and BO SUN KANG ${ }^{4}$
}

\begin{abstract}
${ }^{1}$ Radiation Research Division, Advanced Radiation Technology Institute, Korea Atomic Energy Research Institute, Jeongeup, Jeollabuk 56212; ${ }^{2}$ Radiation Biotechnology and Applied Radioisotope Science, University of Science and Technology, Daejeon 34113, Republic of Korea; ${ }^{3}$ Tanzania Atomic Energy Commission, P.O. Box 743, Arusha, United Republic of

Tanzania; ${ }^{4}$ Department of Radiological Science, Konyang University, Daejeon 35365, Republic of Korea
\end{abstract}

Received October 30, 2019; Accepted March 11, 2021

DOI: $10.3892 / \mathrm{mmr} .2021 .12064$

\begin{abstract}
Prednisolone is an anti-inflammatory drug used to treat a number of conditions, including liver disease and cancer. Numerous studies have demonstrated that glucocorticoids such as prednisolone modified by ionizing radiation can promote anticancer activity in cancer cells. To the best of our knowledge, however, the effect of ionizing radiation on prednisolone structure and cancer cells has not yet been identified. The present study created a novel prednisolone derivative using $\gamma$-irradiation, and its anticancer properties were investigated in liver cancer cells. The present study confirmed the structure of the new prednisolone derivative using liquid chromatogram-mass spectrometry. MTT assays determined the cytotoxic effects of $\gamma$-irradiated (IR)-prednisolone in liver cancer cells. Flow cytometry analysis evaluated apoptosis, mitochondrial membrane potential and cell cycle distribution. Western blotting was used to analyze the proteins associated with apoptosis. The chromatogram profile revealed that IR-prednisolone produced a number of peaks compared with the single peak of the original prednisolone. In contrast to prednisolone, the MTT results showed that IR-prednisolone significantly prevented the growth of liver cancer cells. IR-prednisolone promoted apoptosis and arrested the cell cycle at the G0/G1 stage in Huh7 cells. IR-prednisolone also altered the mitochondrial membrane potential and activated caspase-associated proteins, which activated the intrinsic
\end{abstract}

Correspondence to: Dr Hyoung-Woo Bai, Radiation Research Division, Advanced Radiation Technology Institute, Korea Atomic Energy Research Institute, 29 Geumgu-gil, Jeongeup, Jeollabuk 56212, Republic of Korea

E-mail: hbai@kaeri.re.kr

Professor Bo Sun Kang, Department of Radiological Science, Konyang University, 158 Gwanjeodong-ro, Daejeon 35365, Republic of Korea

E-mail: bskang@konyang.ac.kr

Key words: apoptosis pathways, ionizing radiation, $\gamma$-irradiated glucocorticoids, Huh7 cells, prednisolone apoptotic signaling pathway. In conclusion, IR-prednisolone promoted anticancer effects in liver cancer cells via apoptosis activation. The present study demonstrated that IR-prednisolone may be a potential anticancer agent against liver cancer, although specific molecules have yet to be identified.

\section{Introduction}

Glucocorticoids (GCs) are anti-inflammatory and immunosuppressant agents that have been studied as potential treatments for hematological cancer (1). GCs are also used as drug adjuvants for the prevention and amelioration of non-hematological cancer $(2,3)$. Mechanistically, GCs exert antitumor effects by inducing apoptosis, inhibiting cell proliferation and modulating the inflammatory pathway $(4,5)$. Prednisolone is a commonly used GC for treating liver disease and cancer $(6,7)$. Previous studies have demonstrated that prednisolone increases apoptosis in CCRF-CEM cells $(8,9)$. Prednisolone has also been reported to enhance the metabolism of sorafenib, which can improve the outcome of therapy in the treatment of hepatocellular carcinoma (10). However, GC has anti-cancer effects in haematologic malignancies, but it has limited effects in solid tumors $(11,12)$. Therefore, the development of novel drug derivatives may have notable implications for improving the efficacy for GC-based cancer treatment.

Ionizing radiation is used to modify the structure of numerous drugs, and has been demonstrated to enhance their biological properties in vitro $(13,14)$. Recent reports have demonstrated that $\gamma$-irradiation can create novel GC derivatives, such as $\gamma$-irradiated (IR)-dexamethasone (Dex-IR) and Kenalog-IR, the anticancer effects of which have been confirmed in vitro $(15,16)$. To the best of our knowledge, however, the effects of $\gamma$-irradiation on prednisolone structure, and the mechanism by which it induces anticancer effects, have not yet been explained.

In order to determine the biological activities of new prednisolone derivatives created using $\gamma$-irradiation, the present study evaluated the anticancer activities of IR-prednisolone in liver cancer cells. The present study demonstrated that 
IR-prednisolone decreased the growth of Huh7 and HepG2 cells. Thus, it was hypothesized that IR-prednisolone may have anticancer properties in liver cancer cells.

\section{Materials and methods}

Cell lines, chemicals and reagents. Huh7 and HepG2 cells were acquired from the American Type Culture Collection. The cells were maintained in DMEM containing 10\% fetal bovine serum and 1\% streptomycin/penicillin (all from Thermo Fisher Scientific, Inc.) at $37^{\circ} \mathrm{C}$ in a humidified $5 \% \mathrm{CO}_{2}$ incubator. Prednisolone, MTT and doxorubicin were obtained from Sigma-Aldrich (Merck KGaA). The Muse ${ }^{\circledR}$ Annexin V Dead cell kit and cell cycle arrest package for flow cytometry analysis, and the PVDF membranes were purchased from EMD Millipore. For nick-end labeling, the DeadEnd ${ }^{\mathrm{TM}}$ Fluorometric TUNEL System was purchased from Promega Corporation. The human apoptosis proteome array kit was obtained from Bio-Rad Laboratories, Inc. The ECL detection reagent was bought from GE Healthcare. RIPA buffer was procured from Rockland Immunochemicals, Inc. Bicinchoninic acid (BCA) reagent was obtained from Thermo Fisher Scientific, Inc. The cytochrome c release kit (cat. no. ab65311) was from Abcam. Anti-GAPDH, anti-cleaved caspase 3, anti-cleaved caspase 9, anti-caspase 9, anti-cleaved poly-ADP ribose polymerase (PARP), anti-PARP, anti-caspase 3 , anti-Bcl-2, anti-Bax, and horseradish peroxidase (HRP)-conjugated anti-rabbit IgG and anti-mouse (cat. nos. 2118, 9664, 9505, 9502, 9541, 9532, 9662, 2870, 5023, 7074 and 7076, respectively) were obtained from Cell Signaling Technology, Inc.

Prednisolone modification using $\gamma$-irradiation. Prednisolone was modified using $\gamma$-irradiation under the conditions described by Lee et al (15). Liquid chromatography-mass spectrometry (LC-MS) analysis was used to determine the structural changes in IR-prednisolone. Briefly, a sample solution of prednisolone $(1 \mathrm{~g})$ in $\mathrm{MeOH}$ (1 liter) in chapped vials was exposed to $50 \mathrm{kGy}$ (absorbed dose) of radiation. Irradiation was carried out at ambient temperature using a Cobalt-60 irradiator [Nordion (Canada), Inc.] at the Advanced Radiation Technology Institute, Korea Atomic Energy Research Institute (Jeongup, Korea). The source strength was $\sim 320 \mathrm{kCi}$, with a dose rate at the location of the $10 \mathrm{kGy} / \mathrm{h}$ sample. The prednisolone and IR-prednisolone samples were assessed using the HPLC 1260 system (Agilent Technologies, Inc.) on a YMC-Pack ODS-A 302 column (4.6x150 mm; YMC Co., Ltd.). It was developed at $40^{\circ} \mathrm{C}$ with $1 \% \mathrm{HCOOH} / \mathrm{MeCN}$ (1:1, flow rate, 1.0 per min; detection, $360 \mathrm{~nm}$ ). LC-MS was performed using an Agilent 1100 series LC-MSD system (Agilent Technologies, Inc.) in both positive and negative ion modes. Separation was performed with a YMC-Pack Pro C18 reverse-phase column $\left(250 \times 4.6 \mathrm{~mm}^{2}\right.$ I.D. S-5 $\mu \mathrm{m}, 12 \mathrm{~nm}$; YMC Co., Ltd.) at a flow rate of $1 \mathrm{ml} / \mathrm{min}$. The mobile phase consisted of $0.1 \%(\mathrm{v} / \mathrm{v})$ trifluoracetic acid (TFA; solution A) and 50\% (v/v) acetonitrile in $0.1 \%(\mathrm{v} / \mathrm{v})$ TFA (solution B). Elution was performed by a step gradient from a ratio of 80:20 (solutions $A: B$ ) to $67: 33$ in $18 \mathrm{~min}$; from 67:33 to 60:40 in $12 \mathrm{~min}$; and then from 60:40 to 80:20 in $10 \mathrm{~min}$. The eluted compounds were detected at a wavelength of $520 \mathrm{~nm}$. Electrospray ionization was performed with an ES-APCI mass spectrometer (Agilent Technologies, Inc.). Hydrogen was used as the nebulizing and drying gas. The ESI conditions used were as follows: Nebulizer pressure, 35 psig; drying gas, $12 \mathrm{l} / \mathrm{min}$ at $350 \mathrm{1C}$; ion spray voltage, 4,000 V; and charging voltage, $2,000 \mathrm{~V}$.

MTT cell viability assay. Huh7 and HepG2 cells were grown for $24 \mathrm{~h}$ and treated with prednisolone or IR-prednisolone (5, 10,50 and $100 \mu \mathrm{g} / \mathrm{ml}$ ), or DMSO as negative control for $48 \mathrm{~h}$ at $37^{\circ} \mathrm{C}$. Following incubation, $20 \mu \mathrm{l}$ MTT mixture was added for $2 \mathrm{~h}$ at $37^{\circ} \mathrm{C}$. The medium was replaced by $100 \mu \mathrm{l}$ DMSO to break down formazan precipitates. The absorbances were measured at $562 \mathrm{~nm}$ using an Infinite M200 multimode microplate reader (Tecan Group, Ltd.).

Propidium iodide (PI) staining for cell cycle detection. Huh7 cells were grown for $24 \mathrm{~h}$ before being stimulated with $100 \mu \mathrm{g} / \mathrm{ml}$ prednisolone or IR-prednisolone, or $0.5 \mu \mathrm{M}$ doxorubicin as a positive control, for a further $24 \mathrm{~h}$. Cells were fixed in $70 \%$ ethanol at $-20^{\circ} \mathrm{C}$ for $3 \mathrm{~h}$, then stained with $150 \mu \mathrm{l}$ PI at $25^{\circ} \mathrm{C}$ for $30 \mathrm{~min}$ in the absence of light. The Muse Cell Analyzer (EMD Millipore) estimated the number of stained nuclei.

Annexin V-FITC/PI staining for apoptosis assay. Annexin V-FITC/PI staining determined the number of cells in each population. Huh7 cells were cultured for $24 \mathrm{~h}$. The cells were treated as described in the cell cycle assay. Then cells were harvested, and stained with $100 \mu 1$ Annexin V-FITC/PI solution at room temperature for $20 \mathrm{~min}$ in the dark, as per the manufacturer's directions. The number of apoptotic cells was determined using the Muse Cell Analyzer (EMD Millipore). The Muse software (version 1.1.2; EMD Millipore) evaluated the numbers of apoptotic and non-apoptotic cells in each of the four populations: Live cell; Annexin V (-) and PI (-); early apoptotic cell; Annexin V (+) and PI (-), late apoptotic or dead cell; Annexin V (+) and PI (+); and dead non-apoptotic cell; Annexin V (-) and PI (+).

TUNEL assay. Huh7 cells were grown on microscope slides for $24 \mathrm{~h}$. The treatment conditions used for apoptosis analysis were applied for $12 \mathrm{~h}$, then cells were analysed using the TUNEL assay kit (Promega Corporation) and counterstained using DAPI according to the supplier's instructions. In brief, the cells were washed with cold PBS, fixed with $4 \%$ paraformaldehyde for $20 \mathrm{~min}$ at room temperature. Subsequently, the cells were permeabilized by immersing the slide in $0.2 \%$ Triton X-100 solution in PBS for $5 \mathrm{~min}$. The cells were washed again in cold PBS twice for $2 \mathrm{~min}$. The equilibration buffer was added for $10 \mathrm{~min}$ at room temperature, followed by $100 \mu 1$ terminal deoxynucleotidyl transferase (TdT) reaction mix, covered and incubated at $25^{\circ} \mathrm{C}$ for $60 \mathrm{~min}$. The slides were then immersed in $2 \mathrm{X}$ saline sodium citrate for 15 min to terminate the reaction and washed three times for 5 min each in PBS to remove unbound biotinylated nucleotides. The nuclei were stained with DAPI and incubated at room temperature for $5 \mathrm{~min}$. After mounting, the apoptotic cells were captured on an Olympus IX71 fluorescence microscope (magnification, $\mathrm{x} 40$; Olympus Corporation). To 
quantify the immune-probed cells, the fluorescence intensity was taken in 10 randomly selected images.

Human apoptosis array assessment. Huh7 cells were grown on a $100-\mathrm{mm}$ plate for $24 \mathrm{~h}$, following treatment with $100 \mu \mathrm{g} / \mathrm{ml}$ IR-prednisolone or DMSO for $24 \mathrm{~h}$. Briefly, harvested cells were lysed with 1X RIPA buffer (Rockland Immunochemicals, Inc.), and concentrations were calculated using the BCA protein assay. Then, $250 \mu \mathrm{g}$ total proteins were incubated in the nitrocellulose membrane (NC) overnight at $4^{\circ} \mathrm{C}$. The assay was performed using the apoptosis proteome array kit following the manufacturer's instructions; subsequently, NC membranes were developed on X-ray film for $5 \mathrm{~min}$. Each protein was estimated using Multi Gauge software (version 3.0; FujiFilm).

Western blotting analysis. Huh7 cells $\left(9 \times 10^{5}\right.$ cells/plate) were grown in a $100-\mathrm{mm}$ plate for $24 \mathrm{~h}$. The treatment conditions (for 12 and $24 \mathrm{~h}$ ) were the same as for cell cycle analysis. Protein extraction was performed using RIPA buffer and, the cytochrome $\mathrm{c}$ release kit was used to isolate cytosol and mitochondria fractions. Protein concentrations were determined using the BCA protein assay. Equal volumes of $40 \mu \mathrm{g}$ proteins were separated via SDS-PAGE on $10 \%$ gels, and then transferred onto PVDF membranes and blocked in non-fat milk in tris-buffered saline with $0.1 \%$ Tween-20 (TBST) buffer at room temperature. The membranes were incubated overnight with primary antibodies $(1: 1,000)$ and cytochrome $\mathrm{c}$ antibody $(1: 500)$ at $4{ }^{\circ} \mathrm{C}$, then washed with three changes of TBST buffer. The membranes were incubated with anti-rabbit conjugated-HRP $(1: 3,000)$ and anti-mouse conjugated-HRP $(1: 3,000)$ at room temperature for $1 \mathrm{~h}$, followed by three washes in TBST. The proteins were then visualised using an enhanced chemiluminescence reagent (ECL; EMD Millipore) and exposure to an X-ray film. The blots were scanned and densitometric analysis was performed using ImageJ software (version $1.51 \mathrm{k}$; National Institutes of Health).

JC-1 staining for determination of mitochondrial membrane potential $(\Delta \Psi \mathrm{m})$. The double-emission fluorescence dye JC-1 was used to analyse the status of $\Delta \Psi \mathrm{m}$. Huh7 cells $\left(5 \times 10^{4}\right)$ were grown for $24 \mathrm{~h}$ then treated with the aforementioned conditions for $48 \mathrm{~h}$ or with $50 \mu \mathrm{M}$ carbonyl cyanide 3-chlorophenyl hydrazine (CCCP) for $30 \mathrm{~min}$. Cells were stained with $1 \mathrm{ml}$ DMEM containing JC- 1 dye at $37^{\circ} \mathrm{C}$ for $20 \mathrm{~min}$, then washed with two changes of PBS and reconstituted in PBS. For positive control cells, CCCP at $50 \mu \mathrm{M}$ for $5 \mathrm{~min}$ was used to alter the $\Delta \Psi \mathrm{m}$. JC-1-positive cells were detected using a Cytomics FC500 flow cytometer (Beckman Coulter, Inc.), whereas the red to the green fluorescent cell population was determined using CPX software version 2.2 (Beckman Coulter, Inc.).

Statistical analysis. The data are presented as the mean \pm standard deviation of $\geq 3$ independent experiments. Statistical analysis was performed using Student's t-test and PASW Statistics software version 18 (SPSS, Inc.). Multiple comparisons were performed using one-way ANOVA then Tukey's post hoc analysis. $\mathrm{P}<0.05$ was considered to indicate a statistically significant difference.

\section{Results}

Effects of $\gamma$-irradiation on prednisolone structure. The results of the present study demonstrated that the prednisolone chromatogram had a single peak at the retention time of $19.625 \mathrm{~min}$ with a mass of $361.4 \mathrm{~m} / \mathrm{z}$ (Fig. 1A). The IR-prednisolone chromatogram showed five new daughter peaks detected at retention times of 17.241, 17.397, 22.251, 23.633 and $30.957 \mathrm{~min}$ with masses of 392.9, 393.0, 355.0, 434.8 and $816.6 \mathrm{~m} / \mathrm{z}$ respectively, whereas the mother peak of prednisolone had completely disappeared (Fig. 1B) indicating that $50 \mathrm{kGy} \gamma$-irradiation was able to generate new prednisolone derivatives.

IR-prednisolone prevents the growth of liver cancer cells. MTT assays were conducted to determine the anticancer effects of IR-prednisolone on liver cancer cell lines. IR-prednisolone significantly decreased the viability of Huh7 cells from $83.9 \%$ with prednisolone to $47.4 \%$ with IR-prednisolone at $100 \mu \mathrm{g} / \mathrm{ml}$ (Fig. 2A). A significant decrease in cell viability was observed in HepG2 cells from $120 \%$ with prednisolone to $67 \%$ with IR-prednisolone at $100 \mu \mathrm{g} / \mathrm{ml}$ (Fig. 2B). In contrast with the control group, IR-prednisolone decreased the cell viability of Huh7 cells by $52.6 \%$, whereas the viability of HepG 2 cells decreased by $33 \%$. This indicated that IR-prednisolone was more sensitive to Huh7 cells than to HepG2 cells. Therefore, this cell line was used to investigate the anticancer effects of IR-prednisolone. In order to determine whether IR-prednisolone decreases cell viability by preventing cell cycle progression in Huh7 cells, the present study investigated the DNA content of cells in different phases of the cell cycle. The results of cell DNA content profiles demonstrated a significant increase in the number of cells at $\mathrm{G} 0 / \mathrm{G} 1$ from $62.1 \%$ with prednisolone to $68.7 \%$ with IR-prednisolone. The slightly increased number of cells in the G0/G1-phase indicates that IR-prednisolone may induce cell cycle arrest in Huh7 cells (Fig. 2C and D). These results indicated that IR-prednisolone may prevent the growth of Huh7 cells.

IR-prednisolone increases the apoptosis of Huh7 cells. In order to determine the role of IR-prednisolone in inhibition of cell viability, programmed cell death was evaluated in Huh7 cells. The results of the present study demonstrated that IR-prednisolone significantly increased the population of total apoptotic cells to $36.3 \%$ compared with $11.3 \%$ in prednisolone-treated cells (Fig. 3A and B). In order to further confirm whether IR-prednisolone induced apoptosis, a TUNEL assay was performed. The results demonstrated that IR-prednisolone-treated cells displayed colocalization of TUNEL staining, which stains small fragments of DNA (green), and DAPI (blue), a nucleus and DNA staining dye, compared with prednisolone-treated cells, where no colocalization was observed (Fig. 3C). These results showed that prednisolone transformed through ionizing radiation effectively inhibit the viability of Huh7 cells by inducing certain physiological changes.

IR-prednisolone induces intrinsic apoptosis in Huh7 cells. In order to identify the mechanism of IR-prednisolone-induced 


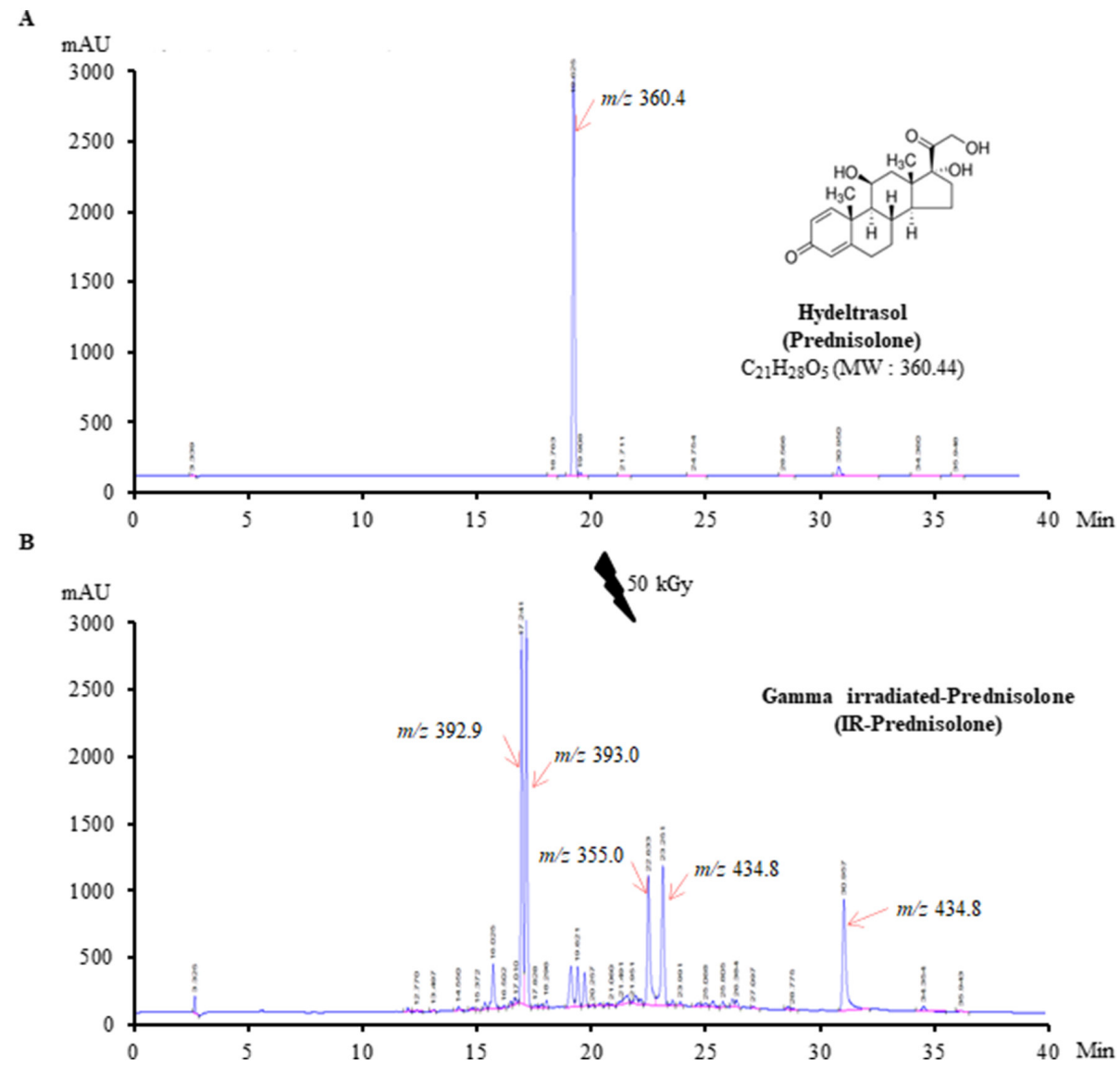

Figure 1. High-performance liquid chromatography results showing that $\gamma$-irradiation produces new prednisolone derivatives. (A) Chromatogram profile of prednisolone. (B) Chromatogram profile of IR-prednisolone. IR-prednisolone, $\gamma$-irradiated prednisolone.

A

Huh7 cells $(48 \mathrm{~h})$

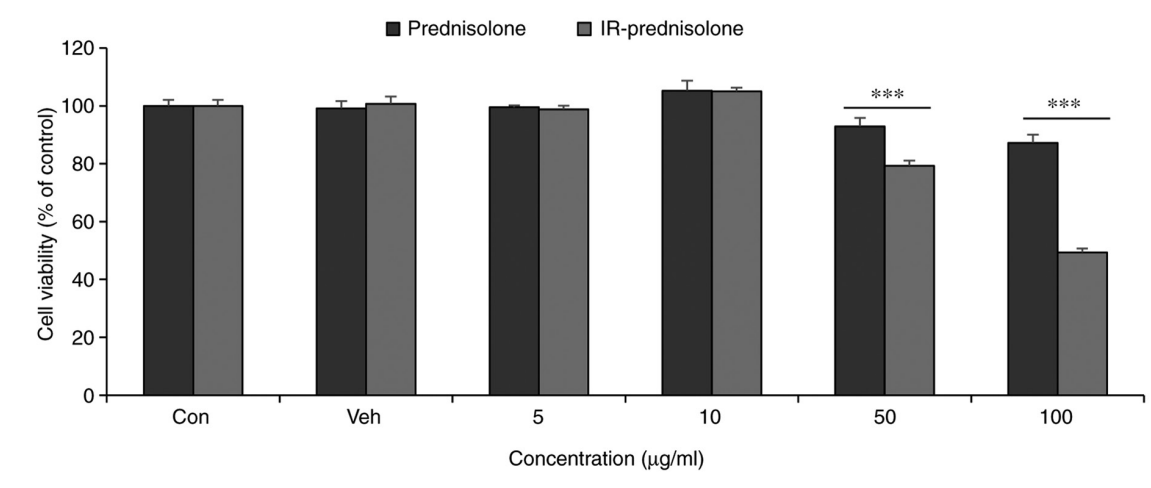

B

HepG2 cells $(48 \mathrm{~h})$

$\square$ Prednisolone $\quad \square$ IR-prednisolone

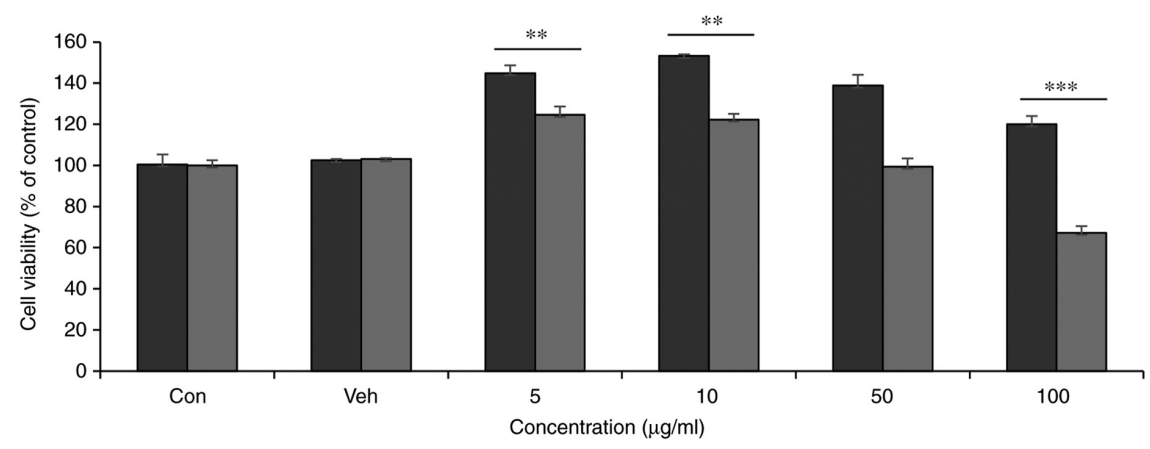

Figure 2. Continued. 
C
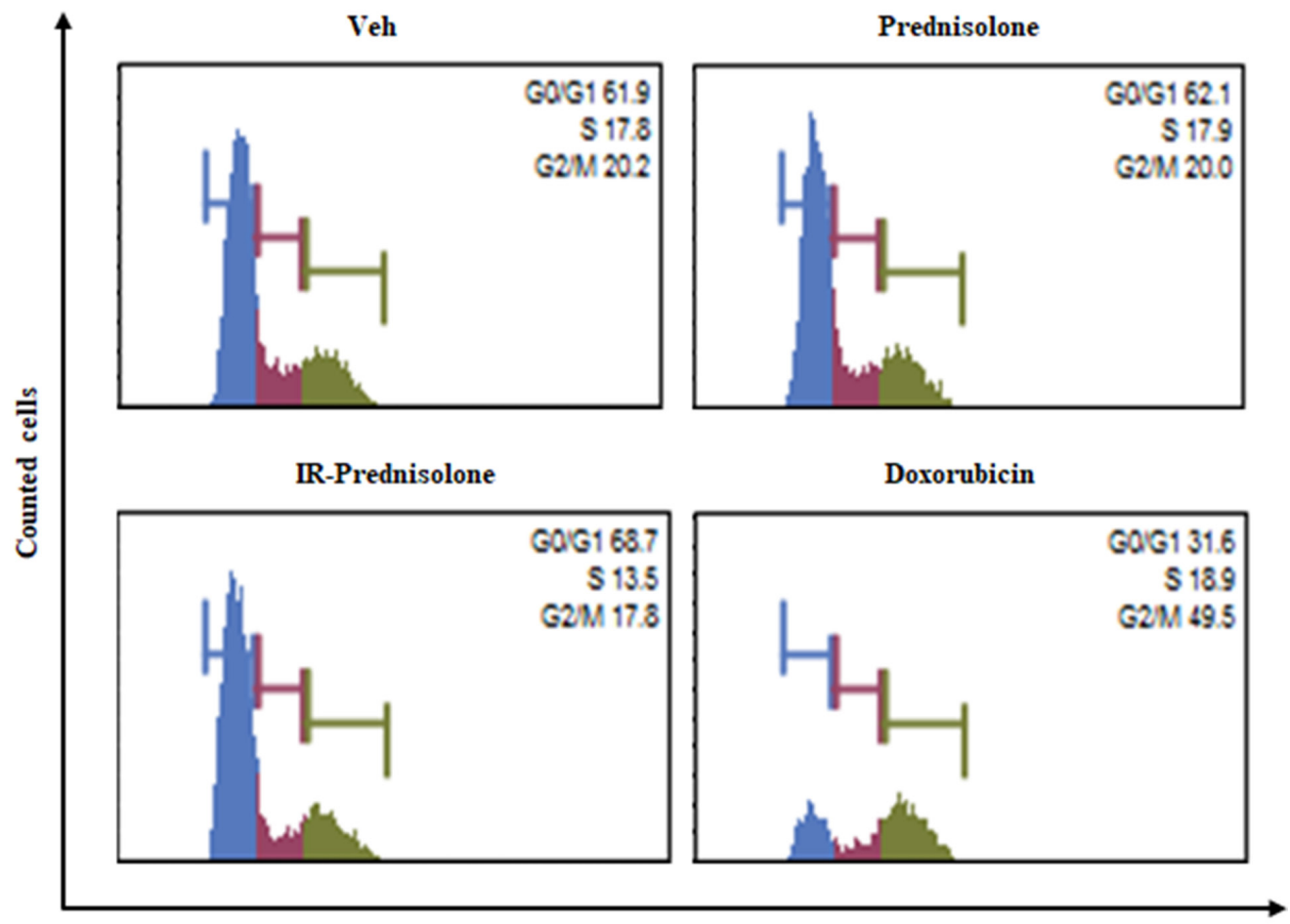

DNA content index

D

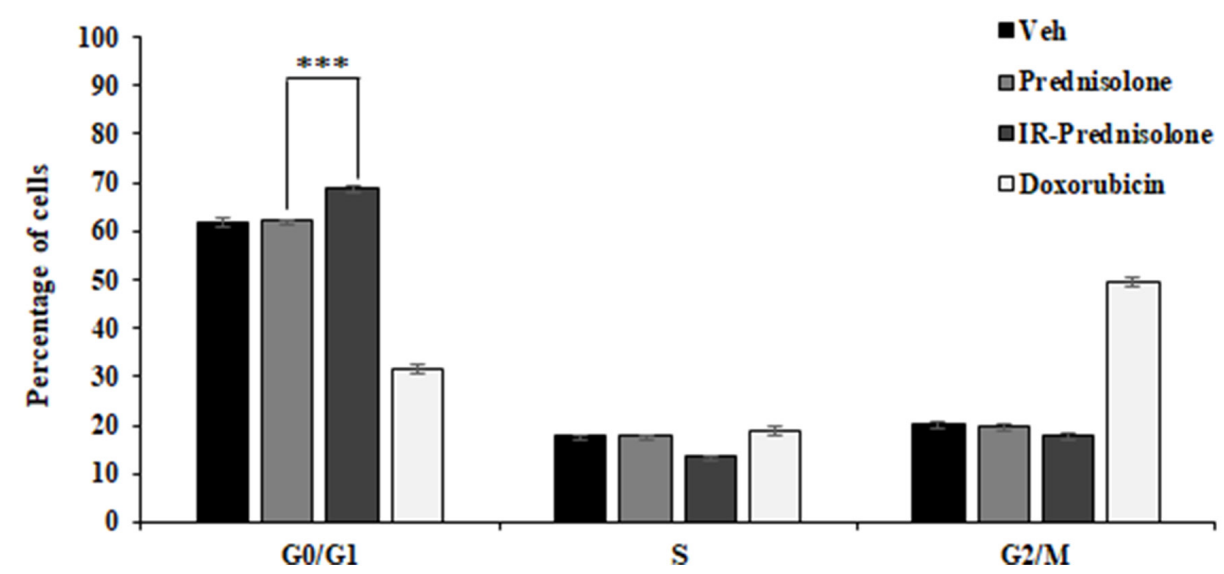

Figure 2. Cytotoxic effects of IR-prednisolone on liver cancer cells. MTT results for (A) Huh7 and (B) HepG2 cells. The bar graph presented the percentage of viable cells normalized to the control. (C) Cell cycle assay performed by Muse Cell Analyzer. (D) Bar graph displaying the percentage of cells in different phases of the cell cycle and the statistical difference between prednisolone and IR-prednisolone at G0/G1 $\left(\mathrm{a} 1=2.1 \times 10^{-12}\right)$. Data are presented as the mean \pm standard deviation of three different experiments. Letter a shows the statistical significance between control and treated groups. ${ }^{* *} \mathrm{P}<0.01,{ }^{* * *} \mathrm{P}<0.001 \mathrm{vs}$. prednisolone. IR-prednisolone, $\gamma$-irradiated prednisolone; Veh, vehicle.

apoptosis, apoptosis-associated proteins were screened using western blotting. The apoptosis array results demonstrated that IR-prednisolone increased levels of cleaved caspase-3, Bax, tumor necrosis factor receptor 1, heme oxygenase-1, $\mathrm{p} 21$, phosphorylated-Rad17 and hypoxia inducible factor- $1 \alpha$, but decreased the expression levels of cellular inhibitor of apoptosis-1, Claspin, Survinin, Bcl-2, Bcl-x and p27 (Fig. 4A). Furthermore, investigation of different proteins connected to apoptosis pathways revealed that IR-prednisolone treatment activated cleaved caspases 9 and 3 , and increased cleaved PARP levels compared with those in prednisolone-treated cells in a time-dependent manner (Fig. 4B). These data demonstrated that IR-prednisolone activates the intrinsic apoptosis pathway.
Effect of IR-prednisolone on $\Delta \Psi \mathrm{m}$. Alteration of $\Delta \Psi \mathrm{m}$ is a critical process in the intrinsic apoptosis pathway (17). Therefore, involvement of intrinsic apoptosis was investigated by JC-1 staining. The results of depolarization status of $\Delta \Psi \mathrm{m}$ demonstrated that IR-prednisolone-treated cells increased JC-1 monomers (green fluorescence) up to $30.0 \%$ compared with $5.6 \%$ observed in prednisolone-treated cells (Fig. 5A). The Bcl-2 family of proteins is known to be a regulator of mitochondrial membrane dysfunction (18). Investigation of mitochondrial membrane dysfunction regulator proteins demonstrated that IR-prednisolone upregulated Bax and decreased levels of Bcl-2 compared with those in prednisolone-treated cells (Fig. 5B). The loss of $\Delta \Psi \mathrm{m}$ has been demonstrated to increase the total amount of cytochrome c movement towards the cytosol and 
A

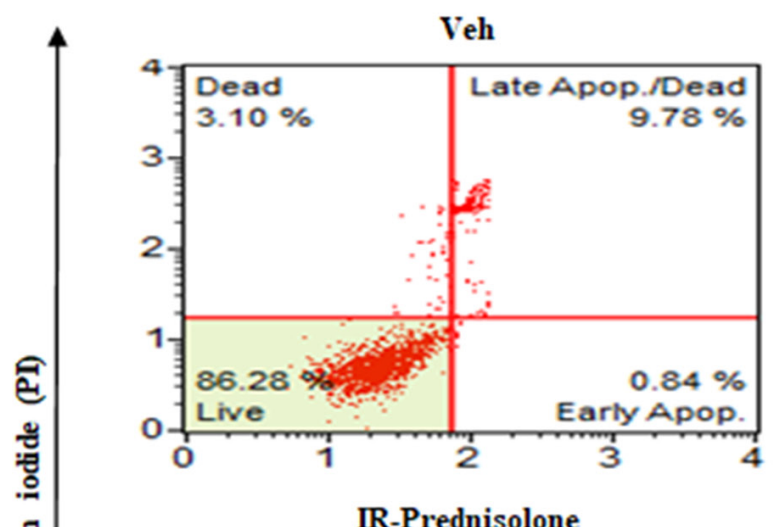

IR-Prednisolone

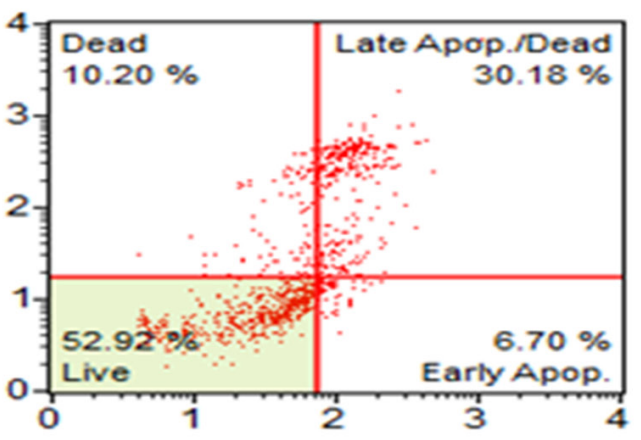

Prednisolone

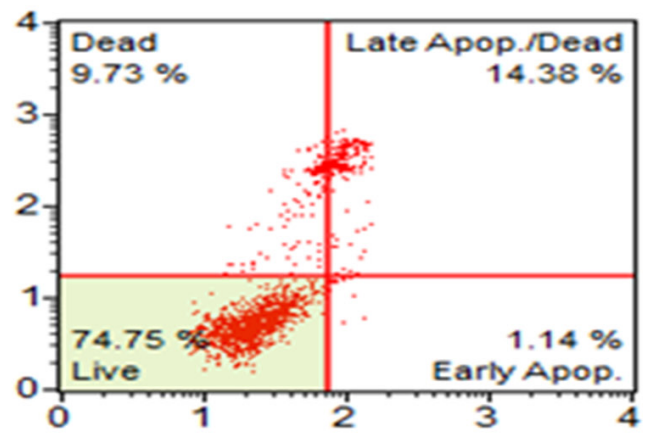

Doxorubicin

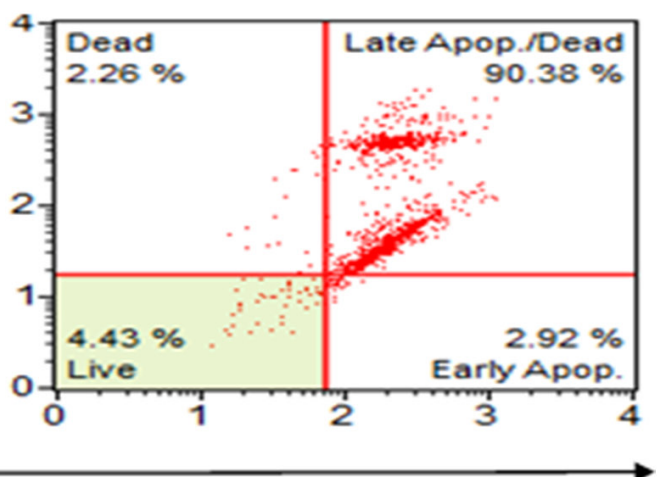

Annexin V-FITC

B

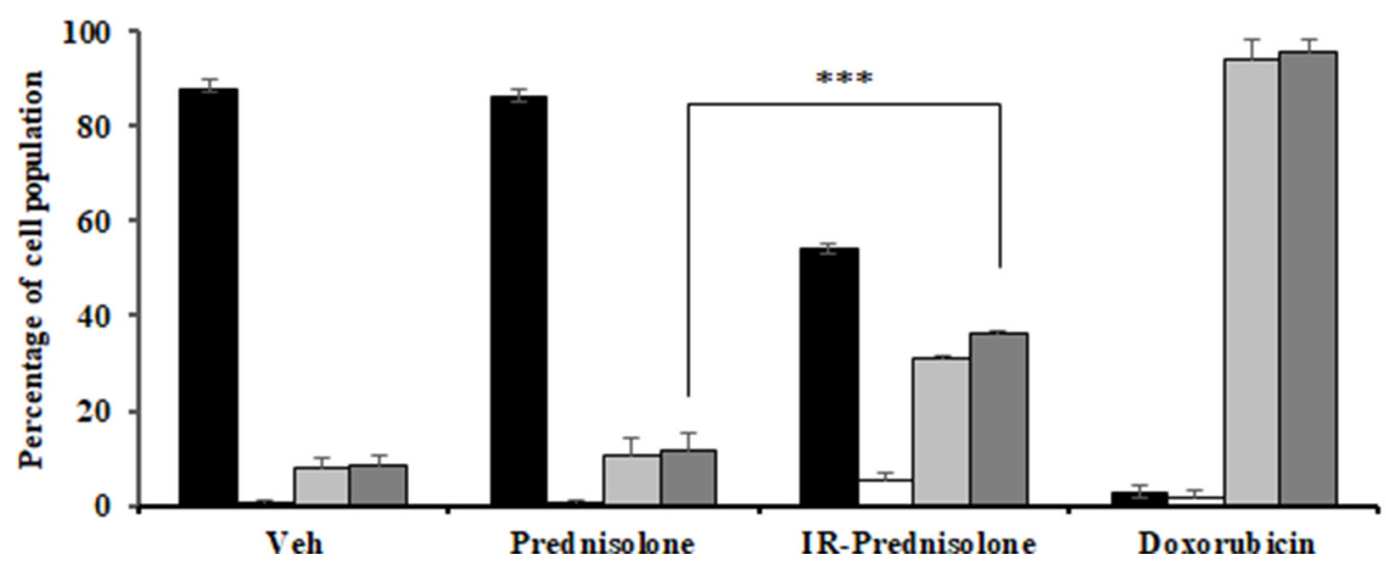

Figure 3. Continued.

mediate apoptosis signaling (19). The present study demonstrated that IR-prednisolone significantly increased cytosolic cytochrome $\mathrm{c}$ levels and decreased the level of mitochondrial cytochrome $\mathrm{c}$ in Huh7 cells (Fig. 5C and D), indicating that IR-prednisolone induced the intrinsic apoptosis signaling cascade.

\section{Discussion}

Prednisolone has been reported to exert anticancer actions in a number of cancer cells, including leukemia, and prostate and oesophageal cancers (20-22). Previous studies have demonstrated that prednisolone increases the level of cytochrome P450 3A4, induces metabolism of sorafenib and enhances the efficacy of chemotherapy during treatment of patients with liver cancer (10). Although prednisolone shows therapeutic roles in numerous types of cancer, the extent of its efficacy remains debatable. In the present study, the structure of prednisolone was improved using $\gamma$-irradiation. Higher levels of cytotoxic effects were observed following treatment with IR-prednisolone compared with those in prednisolone-treated liver cancer cells. Therefore, it was hypothesized that IR-prednisolone may have anticancer activity in liver cancer cells. 
C

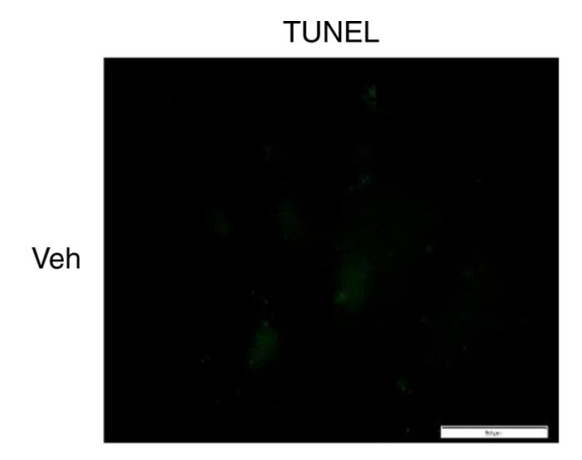

IR-prednisolone
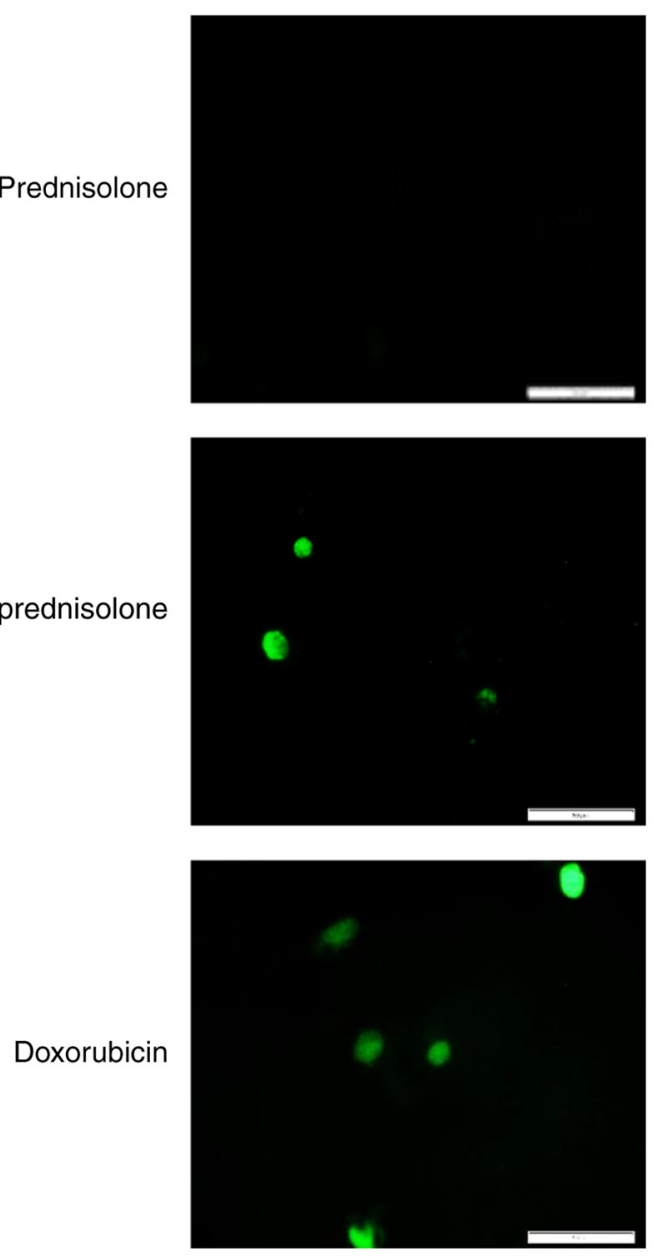
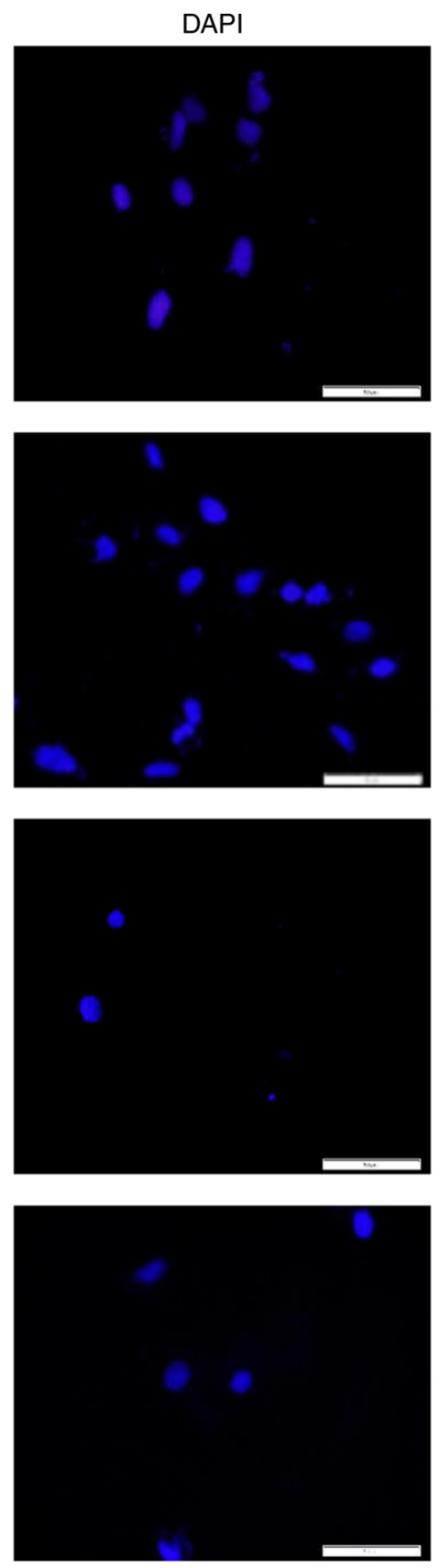
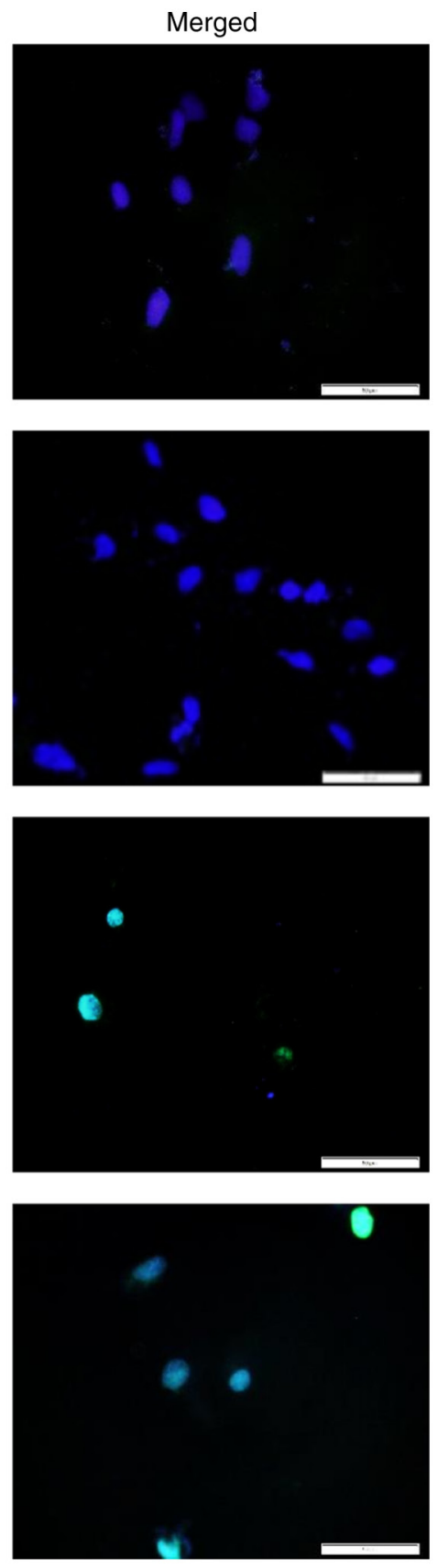

Figure 3. IR-prednisolone induces apoptosis of Huh7 cells. (A) Muse Cell Analyzer was used to determine apoptosis in Huh7 cells. (B) Graph shows the population of apoptotic cells at each stage of apoptosis. (C) DNA fragmentation results. Green fluorescence represents the positive DNA fragments (TUNEL), blue fluorescence indicates nuclei (DAPI). Merged indicates combined DAPI and TUNEL images captured using a fluorescence microscope. Scale bar, $50 \mu \mathrm{m}$.

${ }_{* * * *} \mathrm{P}<0.001$ vs. prednisolone. IR-prednisolone, $\gamma$-irradiated prednisolone; Veh, vehicle.

The present study demonstrated that the use of ionizing radiation was a potential promising technique for structural modification. A number of studies have demonstrated that $\gamma$-irradiation modifies the structures of existing compounds in order to develop novel compounds $(14,23,24)$. Lee et al (15) reported that GCs exposed to IR exhibit improved physiological properties. These studies have demonstrated that ionizing radiation can be used to improve the anticancer activity of drugs. The results presented in Fig. 1 are consistent with previous reports that IR-prednisolone drugs produce several peaks compared to the single peak of prednisolone $(15,25)$. These observations indicate that $\gamma$-irradiation may be used to develop new prednisolone derivatives. The chemical structure for IR-prednisolone was not determined in the present study; however, based on previous observations, it was hypothesized that $\gamma$-irradiation changes the arrangement of functional groups to produce new prednisolone derivatives $(14,25)$.

The potential biological activity of IR-prednisolone was investigated using cancer cells. Among the tested cells (SK-MEL-5 as the skin cancer cell line, MCF7 as the breast cancer cell line and A549 as the lung cancer cell line), IR-prednisolone reduced cell viability only in the liver cancer cell lines, Huh7 and HepG2 (data not shown). Previous reports have demonstrated that $\gamma$-irradiated drugs promote anticancer activity primarily by decreasing cell proliferation and apoptosis induction $(15,25)$. In the present study, IR-prednisolone 

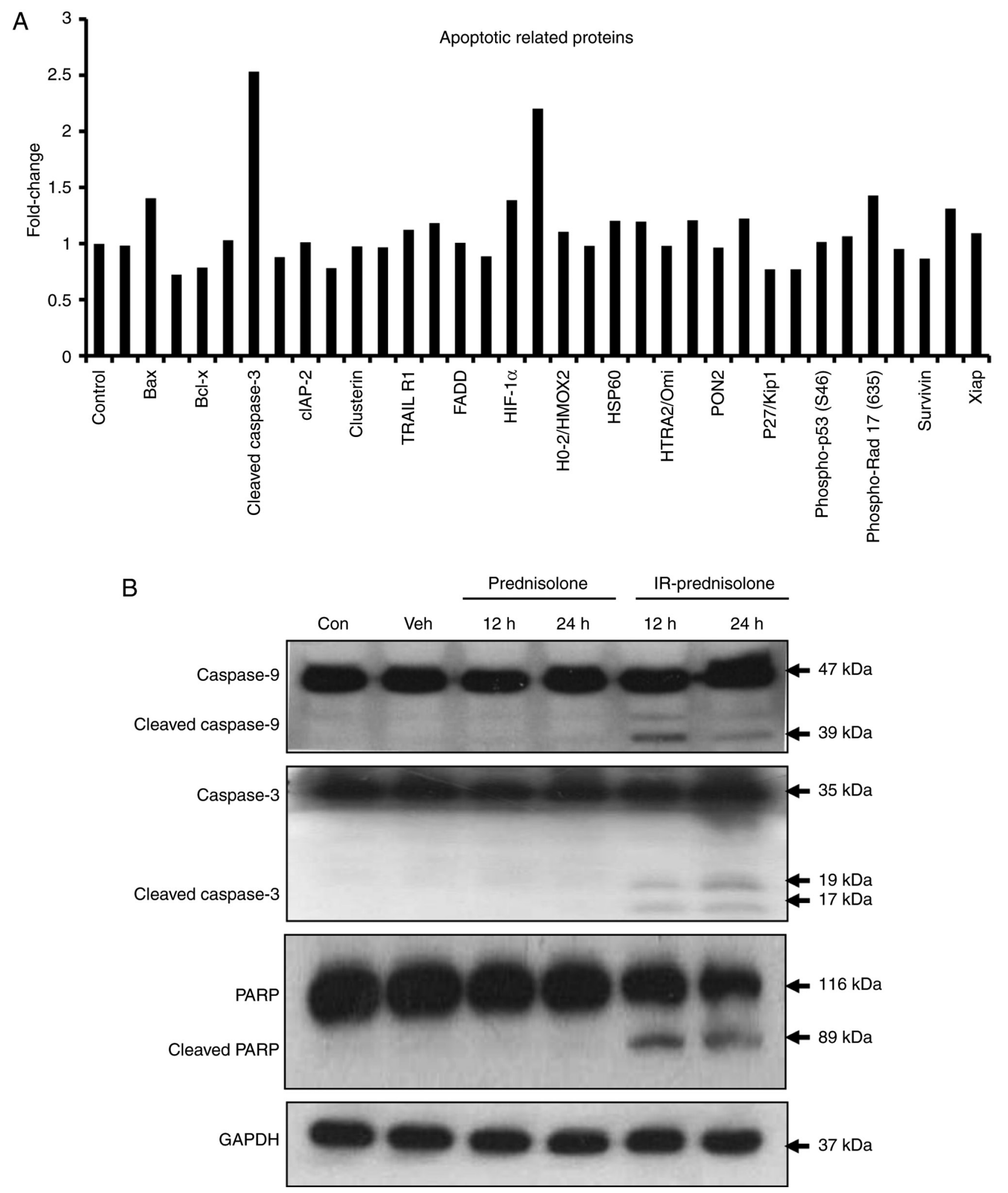

Figure 4. IR-prednisolone induces activation of proteins associated to apoptosis. (A) Bar graph of human apoptosis profile for apoptosis-associated proteins. (B) Western blotting of caspases associated with apoptotic pathways. GAPDH was used as the loading control. IR-prednisolone, $\gamma$-irradiated prednisolone; Veh, vehicle; PARP, poly-ADP ribose polymerase.

significantly decreased the viability of liver cancer cells. As the percentage of apoptotic cells has been demonstrated to increase in numerous types of cancer cell following treatment with $\gamma$-irradiated drugs, it was hypothesized that IR-prednisolone may decrease the viability of liver cancer cells by promoting apoptosis and cell arrest (16). Evading apoptosis is a hallmark of cancer; potential anticancer drugs should therefore promote apoptosis (17). In the present study, apoptosis was accelerated in IR-prednisolone-treated Huh7 cells. DNA fragmentation is considered to be a hallmark of apoptosis, and is controlled by both endonucleases and caspases to form small fragments of DNA (17). DNA fragmentation demonstrated that 

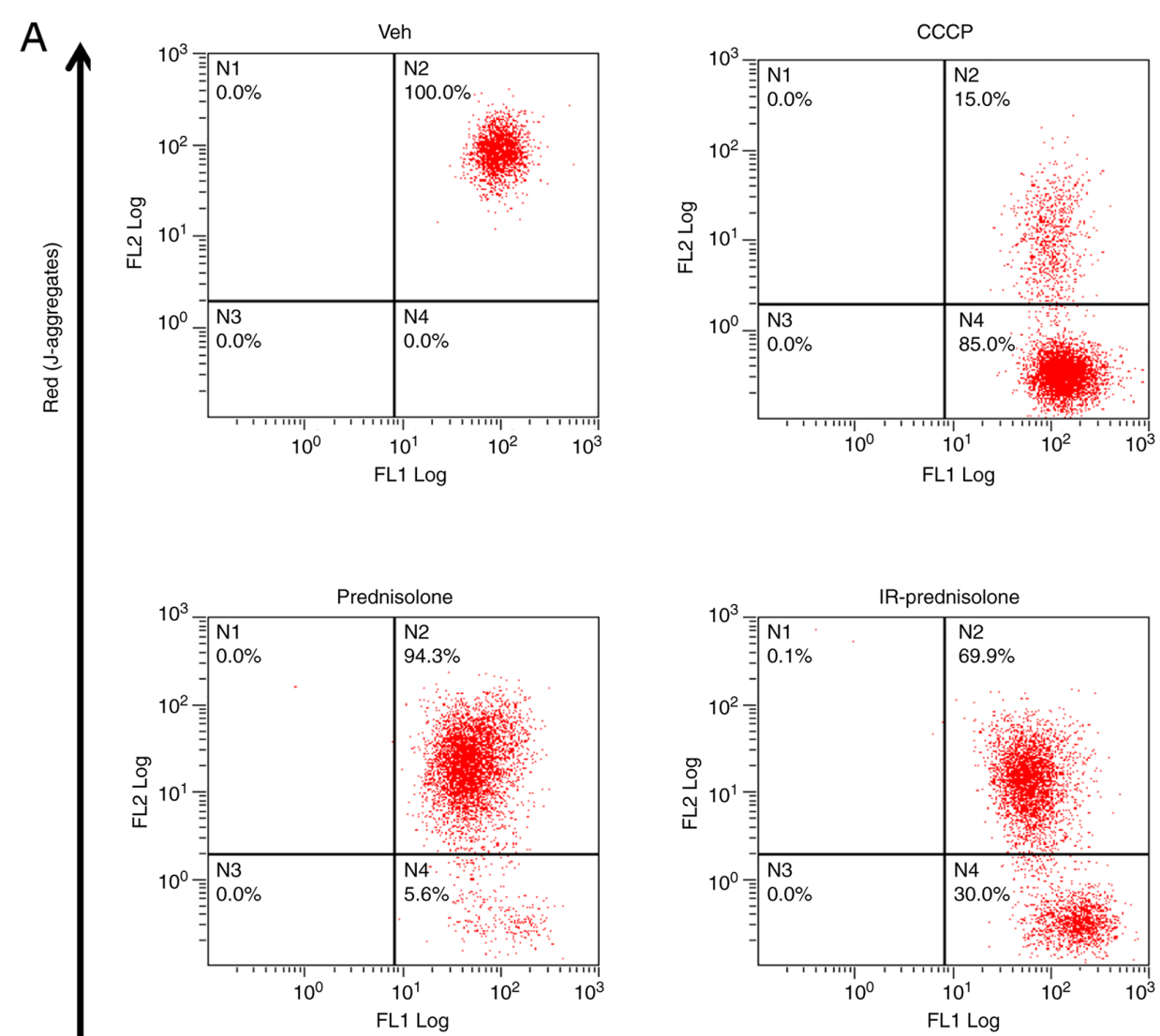

Green (J-monomers)

B

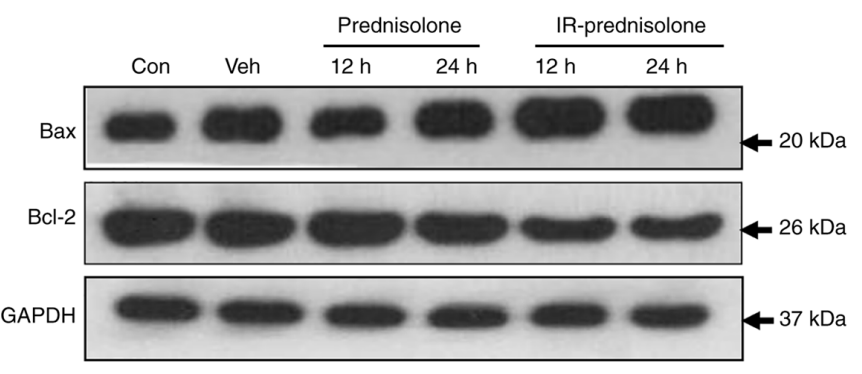

C

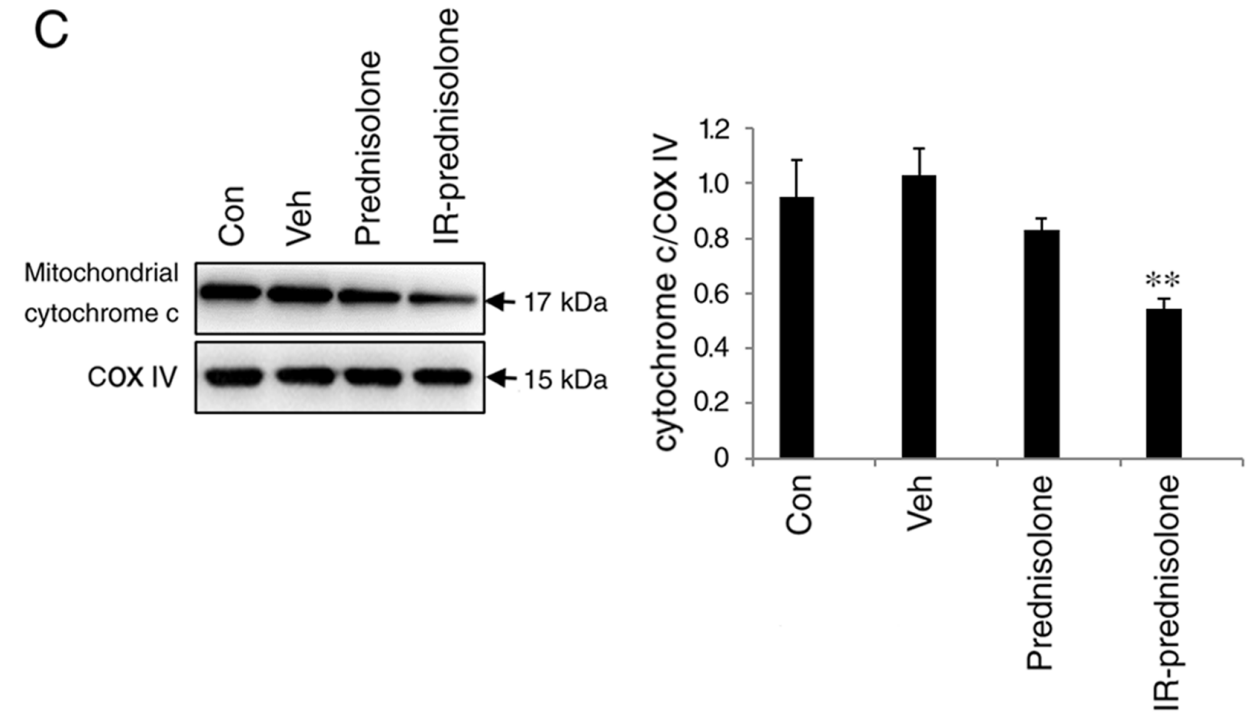

Figure 5. Continued. 

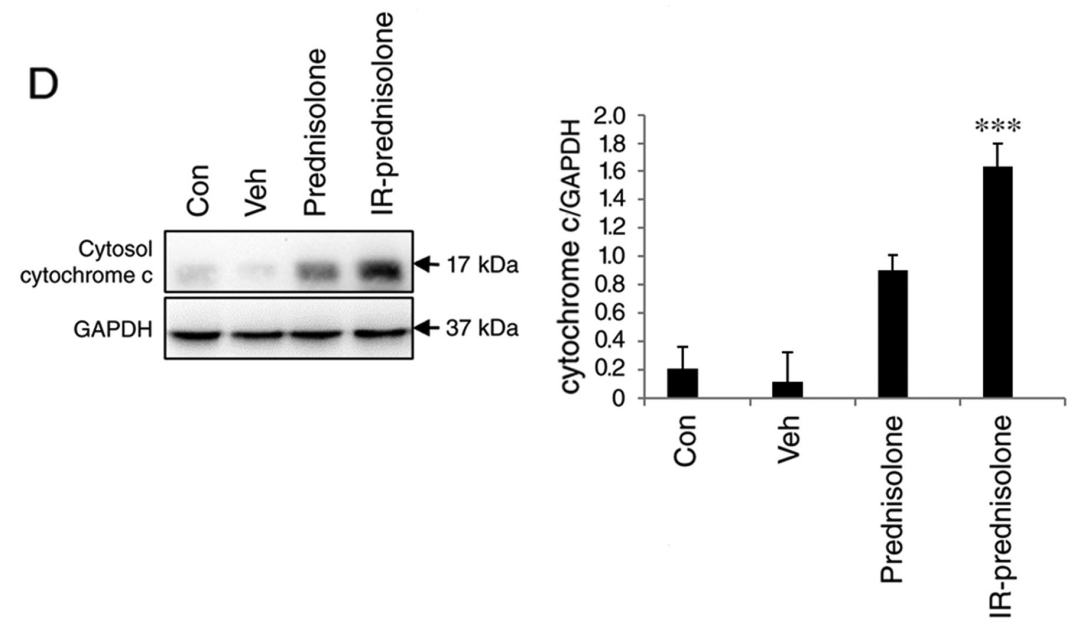

Figure 5. IR-prednisolone decreases the mitochondrial membrane potential of Huh7 cells. (A) JC-1 dye stained the cells and the green/red ratio was then analyzed by CPX analysis. Alteration of mitochondrial membrane potential was induced by CCCP (positive control). (B) Immunoblotting to measure the levels of Bcl-2 family proteins following treatments for $12 \mathrm{~h}$ and $24 \mathrm{~h}$. Western blot analysis of cytochrome c in (C) mitochondrial and (D) cytosolic fractions. ${ }^{* *} \mathrm{P}<0.01,{ }^{* * *} \mathrm{P}<0.001$ vs. prednisolone. IR-prednisolone, $\gamma$-irradiated prednisolone; Con, control; Veh, vehicle; CCCP, carbonyl cyanide 3-chlorophenyl.

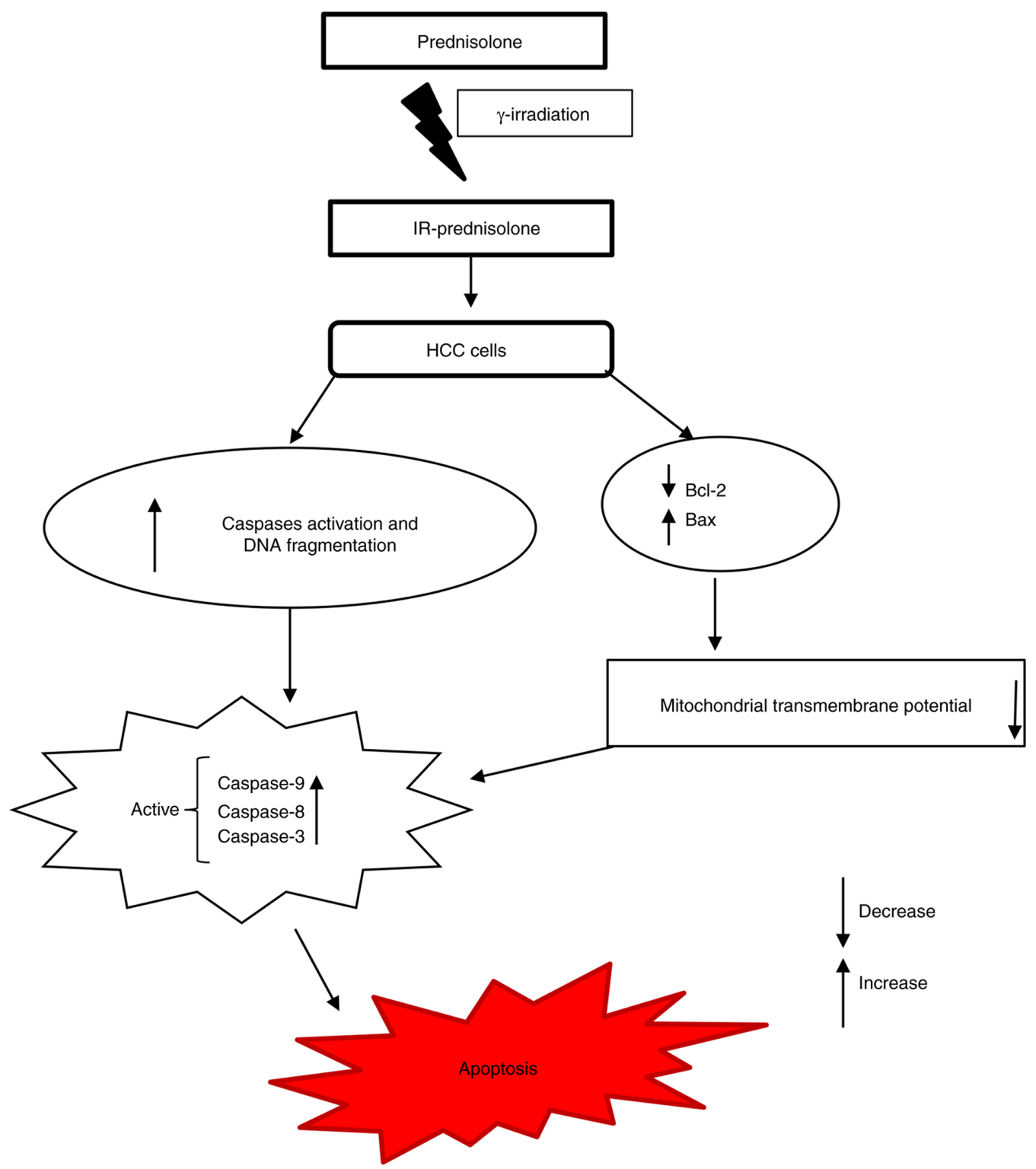

Figure 6. Schematic summary of the key signaling events involved in IR-prednisolone-induced apoptosis of liver cancer cells. IR-prednisolone, $\gamma$-irradiated prednisolone; HCC, hepatocellular carcinoma. 
IR-prednisolone induced apoptosis by a mechanism similar to that reported in other studies (26-28). IR-prednisolone-treated cells were shown to be arrested at $G_{0} / G_{1}$, and similar results have been observed following treatment with Dex-IR (15).

The activation of caspases (aspartate-specific cysteine proteases) controls apoptosis (29). Also, Bcl-2/Bax play an important role in regulating caspase-dependent and caspase-independent apoptosis mediated by the mitochondrial pathway (19). The intrinsic apoptosis pathway is activated by Bax attached to mitochondria, following cytochrome $\mathrm{c}$ movement towards the cytosol, and activation of cleavage of caspase 9, caspase 3 and PARP (30). These events were observed in IR-prednisolone-treated cells, indicating that the intrinsic pathway was involved in IR-prednisolone-induced apoptosis (Fig. 6). Collectively, these findings indicate that IR-prednisolone increased apoptosis by activating the intrinsic apoptosis pathway.

Although the present study demonstrated the anticancer effects of IR-prednisolone, further analysis is required to identify the chemical structure and compounds within the IR-prednisolone mixture. In addition, separating individual fractions to analyse key single compounds and confirm their effectiveness will have to be carried out. Afterward, further research is required to investigate the molecular mechanism underlying these effects.

In conclusion, the present study demonstrated that $\gamma$-irradiation created a new prednisolone derivative. The results of the present study demonstrated that IR-prednisolone prevented the growth of liver cancer cells and arrested cells at the $\mathrm{G} 0 / \mathrm{G} 1$ stage of the cell cycle. IR-prednisolone promoted apoptosis of Huh7 cells via alteration of $\Delta \Psi \mathrm{m}$, DNA fragmentation and decreased Bcl-2 expression levels. Mechanistically, IR-prednisolone activates the intrinsic apoptotic signaling pathway via caspase-dependent activation. However, further research is necessary to identify the specific molecules and mechanisms involved in this effect. The results of the present study indicate that IR-prednisolone obtained through radiolytic transformation technology is a potential candidate for the development of novel therapies for liver cancer.

\section{Acknowledgements}

Not applicable.

\section{Funding}

This research was supported by the Nuclear R \& D Program from the Ministry of Science and ICT, Republic of Korea.

\section{Availability of data and materials}

The datasets used and/or analyzed during the current study are available from the corresponding author on reasonable request.

\section{Authors' contributions}

FJR and HWB conceptualized and designed the study, and wrote the manuscript. FJR, SHK and RAK conducted the experiments, and interpreted and analyzed data. BYC and BSK made substantial contributions to conception and design, and interpreted the data. FJR and HWB confirm the authenticity of all the raw data. All authors read and approved the final manuscript.

\section{Ethics approval and consent to participate}

Not applicable.

\section{Patient consent for publication}

Not applicable.

\section{Competing interests}

The authors declare that they have no competing interests.

\section{References}

1. Coleman RE: Glucocorticoids in cancer therapy. Biotherapy 4: 37-44, 1992.

2. Twycross R: Corticosteroids in advanced cancer. BMJ 305: 969-970, 1992.

3. Kofler R: The molecular basis of glucocorticoid-induced apoptosis of lymphoblastic leukemia cells. Histochem Cell Biol 114: $1-7,2000$.

4. Schlossmacher G, Stevens A and White A: Glucocorticoid receptor-mediated apoptosis: Mechanisms of resistance in cancer cells. J Endocrinol 211: 17-25, 2011.

5. Smith LK and Cidlowski JA: Glucocorticoid-induced apoptosis of healthy and malignant lymphocytes. Prog Brain Res 182: 1-30, 2010.

6. Powell LW and Axelsen E: Corticosteroids in liver disease: Studies on the biological conversion of prednisone to prednisolone and plasma protein binding. Gut 13: 690-696, 1972.

7. Manabe A, Ohara A, Hasegawa D, Koh K, Saito T, Kiyokawa N, Kikuchi A, Takahashi H, Ikuta K, Hayashi Y, et al: Significance of the complete clearance of peripheral blasts after 7 days of prednisolone treatment in children with acute lymphoblastic leukemia: The Tokyo Children's cancer study group study L99-15. Haematologica 93: 1155-1160, 2008.

8. Khanzadeh T, Hagh MF, Talebi M, Yousefi B, Azimi A, Pour Feizi AAH and Baradaran B: Investigation of BAX and BCL2 expression and apoptosis in a resveratrol-and prednisolone-treated human T-ALL cell line, CCRF-CEM. Blood Res 53: 53-60, 2018.

9. Ganbarjeddi S, Azimi A, Zadi Heydarabad M, Hemmatzadeh M, Mohammadi S, Ardehaie RM, Zamani M, Baharaghdam S, Esmaeili S and Ghasemi A: Apoptosis induced by prednisolone occurs without altering the promoter methylation of BAX and BCL-2 genes in acute lymphoblastic leukemia cells CCRF-CEM. Asian Pac J Cancer Prev 21: 523-529, 2020.

10. Noda S, Shioya M, Hira D, Fujiyama Y, Morita SY and Terada T: Pharmacokinetic interaction between sorafenib and prednisolone in a patient with hepatocellular carcinoma. Cancer Chemother Pharmacol 72: 269-272, 2013.

11. Sundahl N, Clarisse D, Bracke M, Offner F, Berghe WV and Beck IM: Selective glucocorticoid receptor-activating adjuvant therapy in cancer treatments. Oncoscience 3: 188-202, 2016.

12. Volden PA and Conzen SD: The influence of glucocorticoid signaling on tumor progression. Brain Behav Immun 30 (Suppl): S26-S31, 2013.

13. Kim WS, Song HY, Mushtaq S, Kim JM, Byun EH, Yuk JM and Byun EB: Therapeutic potential of gamma-irradiated resveratrol in ulcerative colitis via the anti-inflammatory activity and differentiation of tolerogenic dendritic cells. Cell Physiol Biochem 52: 1117-1138, 2019.

14. Badaboina S, Bai HW, Na YH, Park CH, Kim TH, Lee TH and Chung BY: Novel radiolytic rotenone derivative, rotenoisin B with potent anti-carcinogenic activity in hepatic cancer cells. Int J Mol Sci 16: 16806-16815, 2015.

15. Lee EH, Park CH, Choi HJ, Kawala RA, Bai HW and Chung BY: Dexamethasone modified by gamma-irradiation as a novel anticancer drug in human non-small cell lung cancer. PLoS One 13: e0194341, 2018. 
16. Kawala RA, Ramadhani FJ, Choi HJ, Lee EH, Park $\mathrm{CH}$, Chung BY and Bai HW: Kenalog modified by ionizing radiation induces intrinsic apoptosis mediated by elevated levels of reactive oxygen species in melanoma cancer. Oncol Rep 41: $1837-1850,2019$.

17. Adams JM and Cory S: The Bcl-2 apoptotic switch in cancer development and therapy. Oncogene 26: 1324-1337, 2007.

18. Martinou JC and Youle RJ: Mitochondria in apoptosis: Bcl-2 family members and mitochondrial dynamics. Dev Cell 21 92-101, 2011.

19. Wolter KG, Hsu YT, Smith CL, Nechushtan A, Xi XG and Youle RJ: Movement of Bax from the cytosol to mitochondria during apoptosis. J Cell Biol 139: 1281-1292, 1997.

20. Kitazumi I and Tsukahara M: Regulation of DNA fragmentation: The role of caspases and phosphorylation. FEBS J 278: 427-441, 2011.

21. Inaba $\mathrm{H}$ and Pui $\mathrm{CH}$ : Glucocorticoid use in acute lymphoblastic leukaemia. Lancet Oncol 11: 1096-1106, 2010.

22. Venkitaraman R, Lorente D, Murthy V, Thomas K, Parker L, Ahiabor R, Dearnaley D, Huddart R, De Bono J and Parker C: A randomised phase 2 trial of dexamethasone versus prednisolone in castration-resistant prostate cancer. Eur Urol 67: 673-679, 2015.

23. Kataoka M, AnzaiS, Shirasaki T,Ikemiyagi H,Fujii T, MabuchiK, Suzuki S, Yoshida M, Kawai T and Kitajima M: Efficacy of short period, low dose oral prednisolone for the prevention of stricture after circumferential endoscopic submucosal dissection (ESD) for esophageal cancer. Endosc Int Open 3: E113-E117, 2015.
24. Alshammari FM, Reda SM and Ghannam MM: Potential effects of gamma irradiation on the stability and therapeutic activity of anticancer drug, doxorubicin. J Radiat Res Appl Sci 10: 103-109, 2017.

25. Bak DH, Kang SH, Park CH, Chung BY and Bai HW: A novel radiolytic rotenone derivative, rotenoisin $\mathrm{A}$, displays potent anticarcinogenic activity in breast cancer cells. J Radiat Res 62: $249-258,2021$

26. Tharmarajah L, Samarakoon SR, Ediriweera MK, Piyathilaka P, Tennekoon KH, Senathilake KS, Rajagopalan U, Galhena PB and Thabrew I: In vitro anticancer effect of gedunin on human teratocarcinomal (NTERA-2) cancer stem-like cells. Biomed Res Int 2017: 2413197, 2017.

27. Zheng SY, Li Y, Jiang D, Zhao J and Ge JF: Anticancer effect and apoptosis induction by quercetin in the human lung cancer cell line A-549. Mol Med Rep 5: 822-826, 2012.

28. Samarghandian S and Shabestari MM: DNA fragmentation and apoptosis induced by safranal in human prostate cancer cell line. Indian J Urol 29: 177-183, 2013.

29. Varshney L and Dodke P: Radiation effect studies on anticancer drugs, cyclophosphamide and doxorubicin for radiation sterilization. Radiat Phys Chem 71: 1103-1111, 2004.

30. Hengartner MO: The biochemistry of apoptosis. Nature 407: 770-776, 2000.

(i) $\Theta$ This work is licensed under a Creative Commons

Attribution-NonCommercial-NoDerivatives 4.0 International (CC BY-NC-ND 4.0) License. 